PROBLEMS

OF EDUCATION

IN THE $21^{\text {st }}$ CENTURY

Volume 46, 2012

138

\section{MODERN TEACHING OF COMPUTER SUBJECTS TO SUPPORT WEB 2.0 TECHNOLOGIES}

\author{
Milan Turčáni, Zoltan Balogh \\ Constantine the Philosopher University, Nitra, Slovakia \\ E-mail: mturcani@ukf.sk, zbalogh@ukf.sk
}

\begin{abstract}
The subject of our interest is an educational process, which is a dynamic process, changing in time, and can be examined from various viewpoints. We can focus on participants of this process, i.e. on students and lecturers, and observe their mutual relations and interactions. Educational process understood as a dynamic system is an insofar extensive sphere that it provides almost limitless opportunities of observation, modelling and simulation. In this contribution we shall focus mainly on the special part of educational processes - on teaching of subjects focusing on technical and system issues (Logical systems, Architecture of computers, Operating systems and Computer networks), which are specific with their focus on adopting the knowledge on principles and functionality of computer systems for the processing and transfer of information within the studies of informatics.
\end{abstract}

Key words: e-learning, learning management system, blended learning, modelling of Petri nets, adaptive hypermedial systems, model of user, information and communication technology.

\title{
Introduction
}

Static structure of information on the web, the task of which is to provide information, has long been overcome. More and more web software systems, which are more complex than ever before, emerge. From the point of view of application of these systems, there is a more and more frequent necessity to enrich the information space of heterogeneous sources, managed by the mentioned systems, with elements of adaptation to the user and/or the environment, in which the user operates. The aim is to present the user personalized view, if possible only such that are relevant for the user, and in such a way, which suits the given user most (Bielikova and Navrat, 2006).

With the rapid advance of the Internet, e-learning systems have become more and more popular (Gomez-Albarran, 2005), (Jun-Ming et al, 2006). An e-learning system provides the following functions: (1) web delivery of learning content; (2) learning progress recording and portfolio; (3) learning content management, course assessment; and so on (Scorm, 2004).

In the concrete teaching of the above mentioned subjects it is not possible to divide the subject content from the form and employed teaching methods. There is an effort to apply modern forms of instruction and the related methods (distant form of education, combined form of education with an e-learning support, constructively oriented instruction, etc.), with which the students will have the chance to implicitly familiarize during their studies, to gain the necessary experience and, if appropriate, to practically employ them (further training, lifelong education). The aim of this presentation is, after the successful management of designing and creation of e-learning courses for the support of teaching informatics subjects, to introduce the possibilities of personalization of the given activities in the for modelling of educational activities in the LMS Moodle environment. The design of the structure of course, which form a 
part of our selection, will be executed using suitably applied modelling tools, such as modelling using Petri nets and modelling using elements of Adaptive hypermedial systems (AHS).

Education has always been the most popular application area for adaptive hypermedia systems. A number of interesting methods and techniques of adaptive hypermedia were originally developed for various adaptive educational hypermedia systems. In turn, most of the early research on adaptive educational hypermedia were inspired by the area of intelligent tutoring systems (Brusilovsky et al, 1996), (Brusilovsky, 2000) and were created in a trial to combine an intelligent tutoring system (ITS) and educational hypermedia.

Regarding the permanent development in the area of ICT the created e-learning course for the selected topics must remain open to new technologies, opportunities and procedures applicable upon solving projects. The issue and the theory of modelling with Petri nets are both quite well elaborated. Adaptivity in the designed e-activities is an important element of instruction personalization, in which two roles dominate :(1) the role of a tutor, who is responsible for the content and management of created e-activity, (2) and the role of a user, the person who enters education and passes through the educational e-product. The aim of the authors is to attract attention to the principles of creation and application of the user model. This should meet the following two criteria: (1) it should be a hypertextor hypermedia system, (2) and it should be able to adapt hypermedia by using this model.

A common feature of various adaptive Web systems is the application of user models (also known as profiles) to adapt the systems' behaviour for individual users. User models represent the information about users that is essential to support the adaptation functionality of the systems. Adaptive Web systems have investigated a range of approaches to user modelling, exploring how to organize the storage for user information, how to populate it with user data, and how to maintain the current state of the user. The majority of modern adaptive web systems use feature-based approach to represent and model data about modelling the users. The competing stereotype-based approach, once popular in the pre-web area of adaptive interfaces, has lost dominance but is still applied, especially in combination with the feature-based approaches (Brusilovsky and Millán, 2007).

One of the main advantages of using a formal method for student modelling is its robustness. Once this model behaves in a stable and theoretically-correct fashion, the evaluation of a system can be focused on other components (such as the quality of the learning material, learning strategies used, or adaptation capabilities). The future adaptation of learning algorithm would then be able to process each user's interactive behaviour information and simultaneously update the structure of the model (Brusilovsky and Millán, 2007).

In the practice, we often meet with the terms such as e-learning, distant education, flexible education, online and offline education, etc. In connection with e-learning, it is necessary to mention the basic part of e-learning, which are electronic instruction materials. To elaborate a good quality instruction material is different from a simple text writing for classical textbooks (Koprda and Brečka, 2008).

In spite of the fact that the today's period permanently confronts us with the newer and more perfect ICTs, which allow us to realize this flexible and modern way of education, it is necessary to state, based on the authentic facts that the most optimal form with ICT support is the combined form of instruction, the so-called Blended learning.

Combined form draws from the input, running and output tutorials joint with the accessing of the educational materials through LMS (LCMS, CMS) system products. Presentation or contact meetings with participants in education are very operative from the motivating stimulus perspective. Motivation stimulus draws from the idea that a working group has a chance to mutually familiarize, to consult, to find personal contacts, necessary for mutual communication and cooperation. An individual does not feel alone in the study.

Within tutorials, members of the study group shall personally make themselves familiar 
PROBLEMS

OF EDUCATION

IN THE $21^{\text {st }}$ CENTURY

Volume 46, 2012

140

with their tutors. They will receive initial input information, guidelines, directives and advice. Moreover, they will receive authorization through LMS system, to access electronic educational materials, in which they will study, communicate, process and send elaborated exercises, settings, test themselves and do all necessary steps to manage distance study with an e-learning support.

\section{Current Status in Education Modelling}

In the centre of our attention is educational process, which is a dynamic, within times changing system, and explore it from various viewpoints. We can focus on the participants in this process, i.e. students and educators, and investigate their mutual relationships and interactions. We can see education as the process, elements of which are individual educational activities (explanation, exercises, independent works, study, etc.) and to observe the sequence and assessment of these activities with the aim to find their most suitable arrangement.

Educational process understood as a dynamic system is so extensive sphere that it provides us with almost unlimited possibilities of exploration, modelling and simulation. When modelling the educational process, it is necessary to come out of interactive conception, from mutual social interactions of participants in the educational process. A "general model of educational process" was thus elaborated, which includes wider environment, input factors, the process itself as well as its products (immediate results and long-term effects).

The realized models try to catch the overall view of the educational process, all its components and mutual interactions, which originate here. Neither of them understands ICT as a special component of this process, which can enter (and often enters) into mutual relationships with all other components, thus influencing the overall result (product) of this process. Moreover, neither of the given models draws from purely exact statistic processing of data obtained in the educational process, they can easily be affected by a human factor - by observing, experiences, etc.

In the particular practical teaching of topics of the study programme "Applied informatics" it is impossible to divide the contents of these subjects from the form as well as employed methods of instruction. We apply modern methods of instruction (distant education, e-learning, constructively oriented instruction, etc.), with which students will have the chance to implicitly familiarize, to receive the necessary experience and to potentially employ them in their practical life. The meaning of the research work is to propose and create an e-learning course for the support of education of subjects of technical and system character, which should be realized in the educational, management environment of LMS MOODLE.

\section{Model of the Controlled Combined form of Instruction with an E-learning Sup- port}

One of the main goals of the research work at the Department of Informatics is, based on the knowledge of the educational process, to design a model of controlled education with a support of multimedia educational applications based on a detailed description of teaching operations. We design it using schemes describing the stages of system attitude and by means of the description of the instruction system using media, individual levels of creation of pedagogical process, learning models, etc. The model designer is at first interested in the structure of the education process, consequently he tries to define general aims and classify them according to various used taxonomies. Then, he creates a list of most important elements (such as: division of students into groups, inevitable learning materials, teaching aids, programmes, etc.) always with respect to explicitly and clearly defined goals. He then obtains data on students' characte ristics, (learning styles, previous knowledge, interests, motivation, etc.) and then he modifies 
methods according to them, thus forming an operative system of educational activities. Finally, he prepares mechanisms in advance, which allow him to assess, both in the course and after the instruction, the results and use the obtained information for the potential modification of the designed arrangement of the instruction system.

The general system model of instruction includes a clear and exact description of various operations, which run in the pedagogical system. A group of students is a subsystem, composed of elements, processes and aims. The main elements are the teacher (tutor) and the student. Others can be the database of study materials, tests, Internet, television, newspaper and all other things, which can form a part of the system. Processes describe all operations and all functions, which allow the system to achieve the goals. Subsystems include three aspects - evaluation of inputs, evaluation of outcomes (outputs) and feedback. Assessment of inputs relates to the student and his abilities, acquired skills and motivation. Assessment of the results shall allow for the assessment of the function of the system and by means of the network of feedbacks to enter the necessary modifications into the system.

Model of electronic instruction (Figure 1) expresses education without a direct contact of the teacher and the student, when the communication is realized through an electronic medium, which employs the database of learning materials, tests, and through which administration of users, students, test results, etc. is ensured (Balogh et al, 2010).

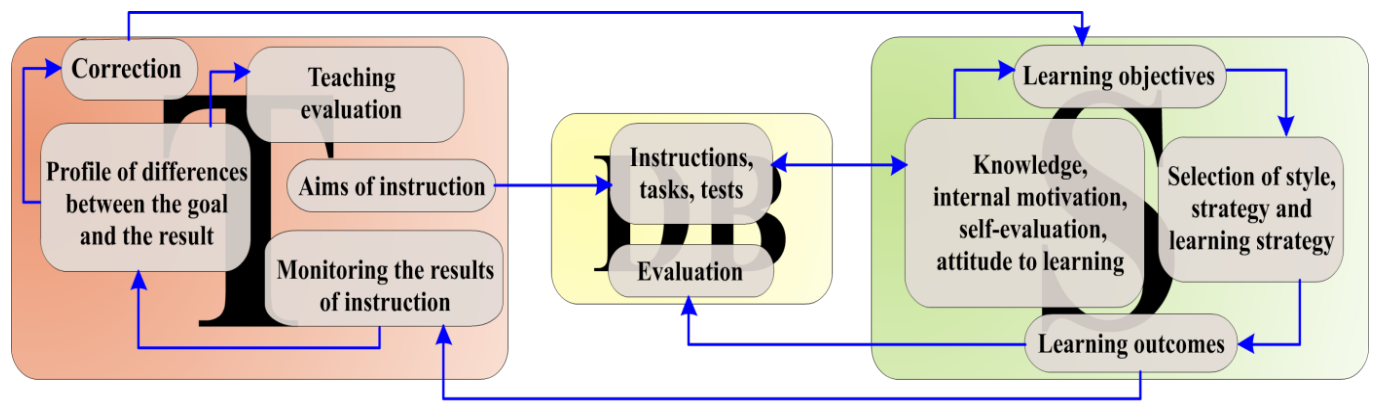

\section{Figure 1: Model of controlled combined form of instruction with the support of e-learning (Balogh et al, 2010).}

Based on input information (information sheet of the subject, printed materials), tutor prepares learning materials and they are saved in the server database in the form of multimedia documents (MUME (MUltiMEdia) applications, www pages, MUME presentations, video tutorials, etc.). These will be available for the student along with the inputs from other sources (reference on internet, forums). Communication between the tutor and the student is provided without a direct feedback, via electronic environment as an answer of the student (LMS MOODLE), which comes to the teacher through electronic environment, the teacher then corrects the student's input and his further reaction. When the tutor checks the required output of the student, the objective of instruction is fulfilled. Such model of instruction is used in distance education, in individualized forms, in e-learning and the like (Turčáni, 2006).

\section{Possibilities of Modelling Using Petri Nets}

The design of the structure of subjects of the system sphere has currently been designed using modelling tools like Petri nets (see below). Regarding the permanent development in the sphere of ICT the e-learning course for the given subject created in such way must remain open to new technologies, possibilities and procedures applicable upon projects solving. The designed Petri net must thus be formulated in a modular way so that it could be complemented or suitably modified in case of need (Nagyová, 2007). 
PROBLEMS

OF EDUCATION

IN THE $21^{\text {st }}$ CENTURY

Volume 46, 2012

Mapping of elements of the modelled system into points, transitions and symbols is a result of abstraction and depends on the purpose, for which the model is being created. When creating the model it is necessary to take into account that while points and transitions and their mutual bonds (edges) exist statically, tokens can originate, vanish and move according to the rules, given by the setting of capacities of places and edges multiplication. When designing any subject's e-course model structure it is inevitable to introduce important terms, which characterize the given structure of courses being designed. They are as follows:

- The point represents a passive element of the system, which is able to remember other objects (tokens). It represents the memory of the Petri net.

- The transition represents an active element, with which events are bound. Its activity is conditioned by the actual status of the system and can modify this status. The transition is modelled by the processor, event, and functional element of the system.

- The token (symbol) represents a passive element, which can move and which can be stored in the point. It typically models data.

Having experience with the designing and creation of the model of educational activity in the subjects of the system character, we managed to present assessment of this method for the purposes of controlling and formation of individual access to instruction for the given field at the Department of Informatics.

For the description of the behaviour of teaching processes the so called serial machines, which, however, have several limitations, e.g. in the number of statuses when modelling complex processes, are suitably used. That is why Petri nets are used for the given purposes, which have originated just on the ground of expanding modelling possibilities of serial machines.

One of the advantages of modelling teaching processes using Petri nets is their formal description, which is complemented by visual graphic depiction. This allows for a precise and exact specification of the teaching process being designed and removal of ambiguity, vagueness and contradiction upon designing. Besides the visual graphic manifestation, Petri nets have also good defined mathematical bases, which can be suitably used in various software tools for the specification and analysis of computer-solved teaching processes (Balogh et al, 2010), (Balogh and Turčáni, 2011).

The target function of LMS controlling instruction is the direction of communication according to the knowledge and skills of the student, thus modifying the amount and complexity of the materials submitted to the student. In the conception of the theory of controlling, the transition from combination procedures to series of sequential and optimized processes is obvious (strategy of continuous evaluation of the reflection of the student's learning and based on this adjustment of the further explanation is comparable with the dual principle of identification and adaptive control). For the sake of description and consecutive controlling of such way of instruction Petri nets can be used.

Let us show an example of description of a simple process of communication with the information system using Petri nets. Individual points in the net represent activities like log in, $\log$ out, information depiction, information update, form filling and form depiction (Klimeš and Balogh, 2005). 


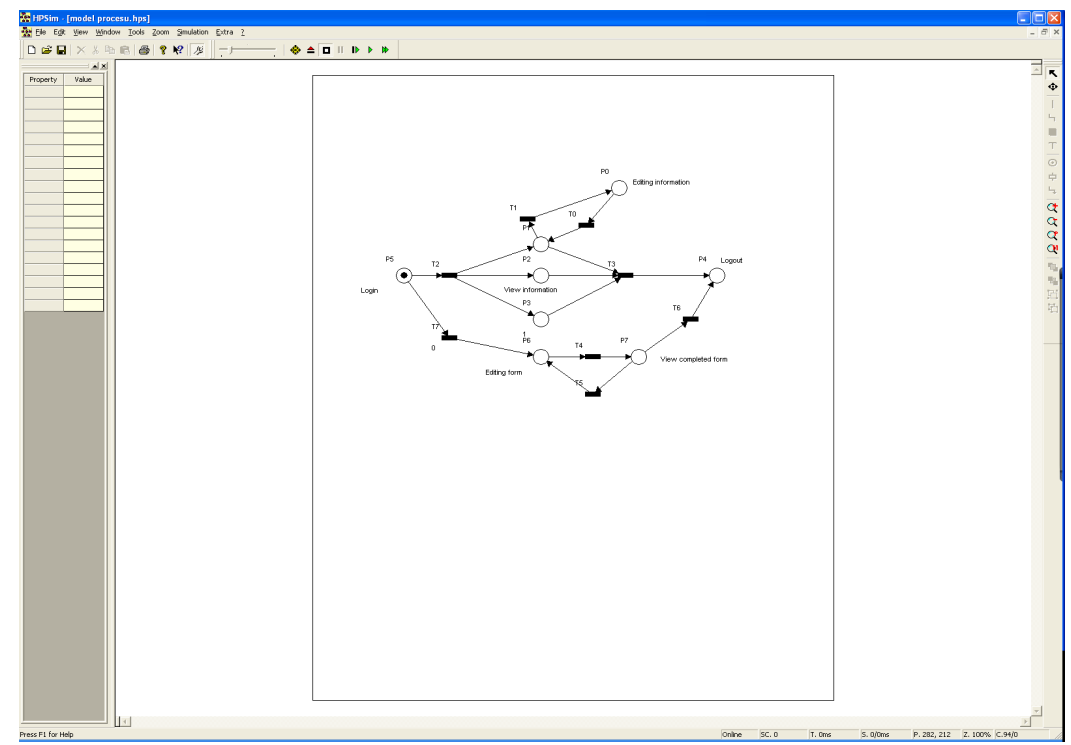

Figure 2: Modelling the process in Petri nets.

Suitable software means is the programme HPSim, which is available free of charge for research and education purposes. Its advantage is a simple installation, simple manipulation and perfect possibility of simulation (mainly of parallel processes). HPSim allows for modelling using P/T Petri nets with inhibitors and testing edges. The product does not work with the hierarchic Petri nets, the hierarchy in the created nets shall be kept by us. The results of work in this area within the research work at the Department of Informatics have been published (Klimeš and Balogh, 2005).

\section{Conclusions}

In our research work at the university we focus not only on the area of presence form of university education, but also on external forms and lifelong education of adults. Each newly created method of instruction is suitable for the particular group of students. We look forward to the questions like this: To what extent it is necessary to adapt the instruction material to students and graduates from the university? Does the university student need personalization of access to the contents and explanation of the contents of education? Is individualization of education at all suitable at the university level? Which is more effective as to time for a university student: to study with e-courses support based on adapted hypermedia systems (AHS) or classical elearning courses? In certain employed adapted e-courses we succeeded in proving statistically significant difference between the instruction with a support of AHS and without these systems. Further research dealt also with the comparison of adaptive techniques from the point of view of the quality of output knowledge of students.

Drawing from the findings accruing from our research as well as personal experience we suggest a wider employment of modelling tools for the creation of educational personalized activities in the Web Base Education environment. We are aware of the fact that the creation of adaptive systems itself is very time consuming. Despite of that we believe that the time invested in the development of adaptively behaving educational process shall be reflected in the form of better prepared students. From the point of view of adaptive techniques we recommend to use in adaptive e-courses the technique of direct leading. When creating e-courses we should not forget the recommendations known for ages: to divide the content of education into small 
PROBLEMS

OF EDUCATION

IN THE $21^{\text {st }}$ CENTURY

Volume 46, 2012

144

fragments, at the end of which a question should be raised in order to verify the comprehension of the particular fragment. In spite of the complexness of creation of models of educational activities and their implementation into the educational process there is an expectation that the problems of authors and teachers shall not discourage others from further utilization of this progressive technology. Nowadays, we can see the shifts in the research and finding suitable adaptive educational activities, when authors preparing materials start to deal not only with technical improvements to the systems in the sphere of Web-Based Education, but they stress the implementation of pedagogical and psychological concepts, such as the learning, revision and forgetting curve. Even if an ideal system, which would suit every student, is a utopia, we can at least get closer to the perfect personalization of education employing well-designed models using Petri nets.

Integration of adaptivity into the process of education using Web-Based Education shall bring us the opportunity to individually access the study. It will offer the students a certain chance to decide, which part should follow. Thanks to the fact that the student can choose alone how to proceed in the study, a certain feeling of freedom at learning and a possibility of nonlinear transition through the learning system are thus formed. Adaptive access of the educational system to students brings to e-learning more elements of the real educational environment, where the teacher very often accesses the students individually and makes provision for their possibilities and abilities.

\section{References}

Balogh, Z., \& Turčáni, M. (2011). Possibilities of modelling web-based education using IF-THEN rules and fuzzy Petri nets in LMS. Communications in Computer and Information Science, 251 (1), 93-106.

Balogh, Z., Turčáni, M., \& Burianová, M. (2010). Modelling web-based educational activities within the combined forms of education with the support of applied informatics with an e-learning support. Proceeding of the 7th International Conference Efficiency and Responsibility in Education (ERIE 2010). Czech University of Life Sciences, p. 14-23.

Bieliková, M., \& Návrat, P. (2006). Modelovanie adaptívnych webových systémov. Štúdie vybraných tém softvérového inžinierstva, STU Bratislava, p. 207-232.

Brusilovsky, P. (2000). Adaptive Hypermedia: From Intelligent Tutoring Systems to Web-Based Education. ITS '00 Proceedings of the 5th International Conference on Intelligent Tutoring Systems, SpringerVerlag London, UK, p. 1-7.

Brusilovsky, P., \& Millán, E. (2007). User models for adaptive hypermedia and adaptive educational systems. The Adaptive Web: Methods and Strategies of Web Personalization. Lecture Notes in Computer Science, Vol. 4321, Berlin Heidelberg New York: Springer-Verlag, p. 3-53.

Brusilovsky, P., Schwarz, E., \& Weber, G. (1996). ELM-ART: An intelligent tutoring system on World Wide Web. Intelligent Tutoring Systems. Lecture Notes in Computer Science, Vol. 1086. Springer Verlag, Berlin, p. 261-269.

Gomez-Albarran, M. (2005). The teaching and learning of programming: A survey of Supporting software tools. Computer Journal, 48 (2), 130-144.

Jun-Ming, Su.et al. (2006). Constructing SCORM compliant course based on High-Level Petri Nets. Computer Standards and Interfaces, 28 (3), 336-355.

Klimeš, C., \& Balogh, Z. (2005). Modelovanie paralelných procesov pomocou Petriho sietí. Technológia vzdelávania, 8 (5), 13-15.

Koprda, Š., \& Brečka, P. (2008). Tvorba e-kurzu s názvom „Počítač pre seniorov“. Trendy vevzděláváni 2008, Olomouc, Univerzita Palackého, p. 350-352.

Nagyová, I. (2007). Využití Petriho sítí při realizaci výuky tvorby animací. VIII. Konferencia doktorandov a mladých vedeckých pracovníkov. Nitra: Univerzita Konštantína Filozofa v Nitre, p. 730-735. 
Milan TURČÁNI, Zoltan BALOGH. Modern Teaching of Computer Subjects to Support Web 2.0 Technologies

Scorm, Sharable content object reference model, 4th Edition Version 1.1. Advanced distributed learning, http://www.adlnet.gov/Technologies/scorm/SCORMSDocuments

/2004\%204th\%20Edition/Documentation.aspx

Turčáni, M. (2006). New approaches in teaching of informatical subjects with the support of LMS MOODLE. Virtual University. STU. Bratislava, p. 9-13.

Advised by Boris Aberšek, University of Maribor, Slovenia

Received: May 16, 2012

Accepted: September 25, 2012

OF EDUCATION

IN THE $21^{\text {st }}$ CENTURY

Volume 46, 2012

\begin{tabular}{|ll}
\hline Milan Turčáni & $\begin{array}{l}\text { Professor, Head of Department of Informatics, Constantine the Philosopher } \\
\text { University in Nitra, Tr. A. Hlinku 1, Nitra } 949 \text { 01, Slovakia. } \\
\text { E-mail: mturcani@ukf.sk } \\
\text { Website: http://www.ki.fpv.ukf.sk }\end{array}$ \\
\hline Zoltan Balogh & $\begin{array}{l}\text { Assistant Professor, Deputy Head of Department of Informatics, Constantine } \\
\text { the Philosopher University in Nitra, Tr. A. Hlinku 1, Nitra 949 01, Slovakia. } \\
\text { E-mail: zbalogh@ukf.sk } \\
\text { Website: http://www.ki.fpv.ukf.sk/zbalogh }\end{array}$ \\
\hline
\end{tabular}

